\title{
Херсонський альманах «Степ» в історії української
журналістики
}

Вадим Лубчак, канд. філол. н., мол. наук. співр. Інституту літератури ім. Т. Г. Шевченка НАН України вул. М. Грушевського, 4 01001 Київ, Україна e-mail: vadim_lubchak@ukr.net (C) Лубчак B., 2018

Стаття присвячена історії виходу у світ херсонського альманаху «Степ», ролі гуртка О. Русова в цьому процесі. У матеріалі акцентується увага на особливостях підготовки збірника до друку, авторському колективі та цензурних утисках.

Ключові слова: альманах «Степ», редактор, упорядник, літературний процес, херсонський літературний гурток.

\section{Актуальність теми}

На відміну від Галичини та Буковини, де під кінець XIX ст. простежувався розвиток української альманахової традиції (виходять у світ літературні збірники «Дністрянка» (1876), «Буковинський альманах» (1885), «Руська хата» (1877), «Ватра» (1887), «Перший вінок» (1887) тощо), на Півдні України через постійні цензурні переслідування, жорсткі утиски, заборони та репресії навіть російськомовна альманахова література в цей час була досить рідкісним явищем.

Після Валуєвського циркуляра (1863 р.) та Емського указу (1876 р.) вимушену двадцятирічну «перерву» було припинено лише 1885 р., коли в Одесі у світ вийшов літературний альманах «Нива», упорядкований Дмитром Марковичем. Уже наступного 1886 р. визначною подією для регіону став вихід херсонського белетристичного збірника «Степ» [15].

Обидва видання мали чимале значення для розвитку національної культури та літератури і не могли залишитися поза увагою учасників не лише мистецьких, але й національно-патріотичних кіл. «Степ» став помітним літературно-мистецьким явищем своєї доби. Видання альманаху в умовах того часу «сприймалося мало не як акт громадянської мужності».

Стан розробки проблеми

Чимало літературознавців та краєзнавців під кін. XX - на поч. XXI ст. також зверталися до дослідження альманаху «Степ» [3], [4], [9], 
але до фундаментального монографічного дослідження ні сучасники «Степу», ні сучасне покоління науковців поки що не вдавались.

Завдання статmі - дослідити створення херсонського альманаху «Степ» та вплив участі в ньому О. Русова. Вплив цензури на видання, реакційно-видавничий аспект створення альманаху та діяльність авторського колективу.

Виклад основного матеріалу

Ідея випуску альманаху «Степ» виникла не в Херсоні чи Одесі, а, так би мовити, на периферії - у когорті єлисаветградських українофілів на початку 80-х років XIX ст. і безпосередньо належала письменникові і юристові Дмитрові Васильовичу Марковичу (1848-1920). За спогадами А. Грабенка-Конощенка, упродовж 1881-1884 рр. місцеві ентузіасти видавничої справи надіслали на розгляд цензурного комітету до Санкт-Петербурга з десяток рукописів як оригінальних, так і перекладних творів, але «всі вони так і загинули в цензурі. Тоді ж таки (1884р.) наш невеличкий гурток український надумав скласти «альманаха» й почав збирати для його матеріали» [5, 121].

Однак, в 1884 р. альманаху не судилося побачити світ: у зв’язку 3 розпадом українофільського руху в повітовому Єлисаветграді (тепер м. Кропивницький), на початку 1885 р. його активні учасники були заслані до губернського Херсона. Майже однією хвилею заслання до Херсона переїхали Олександр та Софія Русові, Феофан Василевський, який на Півдні побереться з Людмилою Березіною - згодом знаною в Україні письменницею Дніпровою Чайкою, Дмитро та Олена Марковичі, Андрій Грабенко-Конощенко, Борис Грінченко та ін.

Більшість із них працювали в губернському земстві й фактично відразу після переїзду створили неофіційний гурток українофілів під керівництвом О. Русова, який існував неповних півтора роки (в 1887 його було заборонено). Незважаючи на утиски і перепони, ці громадські діячі активно займалися літературно-мистецькою, видавничою діяльністю та здійснювали просвітницьку роботу.

У черговий раз зустрівшись на квартирі у Дмитра та Олени Марковичів, гуртківці «почали міркувати про свій альманах, переглядали ті матеріали, що збереглися, і підшуковували нових, щоб альманах вийшов більш-менш «солідним» [13, 78]. Повернутися до ідеї видати запланований в Єлисаветграді літературний збірник вирішили тому, що рукописам окремих творів було складніше подолати цензурні бар’єри. У своїх спогадах Софія Русова це пояснює таким чином: «Хоч правильного розвитку літератури і не було, але настала мода на збірники, до них і цензура ставилася якось лагідніше, і розходилися вони ліпше, бо в них більше авторів брало участь» $[13,84]$.

Внаслідок праці цих гуртківців і було видано альманах «Степ». Херсонський белетристичний збірник», редактором якого був Д. Мар- 
кович. Цей збірник, навіть усічений цензурою та 3 частиною російськомовних матеріалів, засвідчив бажання південних літераторів, попри тяжкі умови царсько-російських переслідувань і цькувань, бути невід'ємною частиною українського літературно-мистецького процесу.

За спогадами Софії Русової, відповідальність за підготовку і випуск «Степу» взяло на себе передовсім подружжя Марковичів. С. Русова відзначала, що «на чолі цієї справи в Херсоні стала офіційно Є. І. Маркович (Олена Іванівна, дружина письменника - В. Л.), як видавець, а неофіційно сам Д. В., як душа цілого збірника... До збірника всі ставилися прихильно й підтримували його, хто чим міг» $[13,163]$.

Розуміючи складність подолання цензурних бар’єрів, упорядники певний час шукали авторитетну людину, яка б усвідомила важливість виходу у світ збірника й виступила його «адвокатом». Під час однієї 3 розмов про «Степ» співавтори вирішили звернутися за допомогою до відомого українського письменника й видавця з Санкт-Петербурга Д. Мордовця. Колишній урядовець і цензор Мордовець відгукнувся на прохання про допомогу й таки посприяв гуртківцям. В оповіданні «Будяк», поданому до альманаху, він згадував: «Писали оце земляки до мене, що загадали вони невеличкий «збірничок» видати - «Степом» називається, та й прохали мене, щоб і я хоч маленьку квіточку у той їх віночок із степових квіток укинув» $[15,10]$.

Загалом, до альманаху увійшли твори як знаних на той час літераторів, так і молодих, невідомих широкому загалу авторів. Так, крім Д. Мордовця, співавторами збірника виступили також Іван Левицький (Нечуй) з Кишинева, Михайло Грушевський (Заволока) з Астрахані, Павло Тулуб та Петро Залозний з Києва, Кость Іващенко (Шрам) з Одеси, що дало змогу значно розширити географію учасників видання.

Згідно зі спогадами авторів альманаху більшість творів було підготовлено до друку в першій половині 1885 р. У середині 1885 р. збірник був уже фактично упорядкований, адже найпізніше написані твори датуються початком літа. Наприклад, про час написання оповідання «Будяк» Д. Мордовець згадує: «писав у Петербурзі, року Божого 1885-го, червня 18-го» [15, 11], а про дату завершення твору «Тарасенко» Пенчуківця говориться: «1885 г., июня 10 дня, Херсон» [15, 350]. Того ж літа рукопис «Степу» був відправлений до Санкт-Петербурга. У спеціальному дозвільному «прошенії» секретар херсонської губернської земської управи, колезького асесора О. Русова йдеться: «Бажаючи видати в м. Санкт-Петербург в типографії м. Стасюлевича у 1200 примірниках прикладене в особливій посилці рукопис під заголовком - «Степ». Херсонська беллетрістічний Збірник», - честь маю уклінно просити Санкт-Петербурзького цензурного комітету схвалити до друкування означену рукопісь, а також не залишити мене повідомленням про резолюції по справжньому моєму прошению» $[10,14]$. 
Восени 1885 р. почався розгляд рукопису «Степу» цензурою. У центральному державному історичному архіві Росії в м. Санкт-Петербурзі зберігаються подробиці про здійснення цієї процедури. Зокрема, херсонський дослідник I. Немченко пише, що «в доповіді цензора Фреймана за жовтень 1885 р. про передачу з Головного управління в справах друку на розгляд цензурним комітетом "рукописи на малорусском наречии под заглавием «Степь»” наводяться аргументи щодо заборони ряду творів». Так, до збірника мав увійти вірш Дніпрової Чайки «Думка. Перед портретом Тараса Шевченка», але, як визнав цензор, виходячи зі змісту твору, у душі автора «живе надія що Украйна ще не зовсім померла, що вона може відродитися, і що брати один одному протягнуть руки і будуть дружно діяти на захист їі», а тому «безсумнівно, що в цьому вірші панує політична тенденція збудливого характєра» $[9,16]$. На думку Фреймана, у поезії тієї ж авторки «Засуха» висловлено «занадто прозорий натяк на утиснення у нас свободи думки і слова», a іiї вірш «Сестрицям-українкам» пройнятий «такою ж тенденцією, вороже російської національності», як і в згаданій «Думці...». Також цензор не рекомендував до друку і твір Сестри Н. «Баба Горпина». Цей твір, як і частина інших, потрапили під гриф «до друку не дозволяти». Наприклад, в анотаціях на вихід «Степу» перераховуються подані до нього твори, зокрема поезія В. Чайченка (Б. Грінченка), стаття С. Р. (Софії Русової) «Кілька слів з приводу ставлення північно-російської літератури на південь від Росії», але до узгодженого цензурою варіанту альманаху ці матеріали не увійшли. Дослідники припускають, що їх також не пропустила цензура. На думку I. Немченка, для збірника це була відчутна втрата, оскільки саме стаття С. Русової була profession de foi даного видання.

Упродовж кількох місяців «Степ» уперто мандрував коридорами царської цензури, а херсонці чекали дозволу на друк. Про очікування дозволу друкувати альманах Д. Маркович у листі до М. Грушевського від 24 березня 1886 року писав: «Степ» поїхав у «Головне Управління у справах друку». Коли розрішать не знаю; коли друкуватимем - не знаю. Коли прийде, тоді й в друкарню піде» [7]. Наприкінці травня 1886 р. цензура таки дозволила друк збірника за винятком «небезпечних» творів, «всю остальную часть сборника «Степь» как незаключающую в себе ничего тенденциозного, дозволить к печати под условием соблюдения в тексте правил правописания русского языка, согласно Высочайшему повелєнию от 18-30 Мая 1876 года» [10, 18].

Восени 1886 р. суттєво усічений цензурою «Степ» нарешті побачив світ. Він вийшов тиражем 1200 примірників та коштував 1 р. 25 коп. Збірнику судилося стати другий колективним виданням, яке з'явилося на Півдні України за російського царювання й містило більшість творів українською мовою. 
Честь відкрити перший номер белетристичного збірника випала відомому на той час російському поету, юристу Павлові Тулубу (батькові Зінаїди Павлівни Тулуб, авторки широкопанорамної дилогії «Людолови» та роману «В степу безкраїм за Уралом» про життя Т. Г. Шевченка на засланні) - віршем «В степи»:

По степи проезжал я раздольной...

Полный месяц на небе сіялъ,

Ветер юга прохладный и вольный

Мне с любовью лицо целовал... $[15,1]$

За оцінкою критиків, ця поезія особливої вишуканості в літературному плані собою не являє. Про неї, а також про ряд інших робіт, уміщених в альманасі «Степ», зокрема О. Браунера, Пенчуківця, А. Конощенка, П. Залозного, відомий критик Іван Франко сказав: «...речі слабкі, хоча деякі, як на початкуючих авторів, варті того, щоб їх прочитали» $[16,116]$. Наступним твором, опублікованим в альманасі, було оповідання «Будяк» відомого петербурзького письменника Данила Мордовця.

Д. Мордовець, як зазначалося вище, літератор і видавець із СанктПетербурга, колишній цензор, відомий урядовець, якому судилося бути ключовою фігурою виходу альманаху. «Це завдяки його авторитету і надзвичайній популярності столична друкарня узялася видрукувати херсонський збірник», - відзначає дослідник М. Каляка $[4,3]$. Заслугу Д. Мордовця у виході «Степу» підкреслюють чимало інших вчених серед яких I. Немченко [10], Я. Голобородько [2], В. Загороднюк [3].

Одним із важливих надбань збірника є творчість землячки «Степу» Дніпрової Чайки. Вона представлена в збірнику двома віршами «На лимані» та «Зорі».

Загалом до «Степу» увійшли такі твори: вірші П. Тулуба («В степи»), Дніпрової Чайки («На Лимані», «Зірка»), А. Конощенка («В невеселую годину»), П. Залозного («Сиротина»), оповідання Д. Мордовця («Будяк»), І. Левицького («Невинна»), О. Браунера («Идиллия в плавнях», «Бог простит», «Тирса»), Д. Марковича («Йван из Буджака», «Два платочки», «Шматок», «Омелько Каторжний»), М. Заволоки («Бідна дівчина»), Пенчуківця («Тарасенко»), історична драма I. Карпенка «Бондарівна»; статті М. Ганенко («Сімейно-майнові відносини селянського населення в Єлисаветградському повіті (Матеріали по звичайному праву»), О. Маркович («Весільні пісні в Єлисаветградському повіті»), К. Шрама («Українська село за творами р. Старицького та Кропивницького»), О. Русова («Обласний початок в земській статистиці»), замітка I. Левицького «Пісня про Бондарівну». Як видно зі змісту альманаху, у жанровому та ідейно-тематичному плані публікації були досить різнорідними. 
Твори, які увійшли до «Степу», носять не лише літературну, але й краєзнавчу, археологічну, фольклорну, правознавчу вартість. Рецензуючи надруковані в збірнику наукові праці, I. Франко називає «найважливішою» серед розвідок статтю Марії Ганенко «Сімейно-майнові відносини селянського населення в Єлисаветградському повіті (Матеріали по звичайному праву)». Також позитивно оцінює дописи О. Русова та О. Маркович. 3 певною іронією говорить І. Франко як про «свого роду рідкість» про статтю К. Шрама (Іващенка) «Украинская деревня по произведениям Старицкого и Кропивницкого». Цю «спробу критики найновішої української драматичної літератури» Франко оцінює негативно, адже вона «не дає нам нічого нового, ні нових фактів, ні думок, крім банальних речей, поданих значно пластичніше у самих драмах» $[16,115]$. Серед художніх творів альманаху, на думку I. Франка, «гідними уваги» можуть бути передовсім драма I. Карпенка-Карого «Бондарівна», оповідання I. Нечуя-Левицького («Невинна»), Д. Мордовця («Будяк») та М. Заволоки (Грушевського) «Бідна дівчина». Решта матеріалів, тобто оповідання Д. Марковича, О. Браунера, Пенчуківця, вірші Дніпрової Чайки, П. Тулуба, А. Конощенка (Грабенка), П. Залозного, як вважає критик, $\epsilon$ «речі слабкіші, хоча деякі, як на початкуючих авторів, варті того, щоб їх прочитали» $[16,116]$. Проте пізніше в своєму «Нарисі історії українсько-руської літератури до 1890 р.» I. Франко внесе певні «поправки» до оцінки збірника та окремих його авторів. Зокрема, про твори упорядника альманаху він зазначить, що в них автор «виявив неабиякий белетристичний талант». Окрасою збірника стала новелістика Д. Марковича. I твір російською мовою «Йван из Буджака», і оповідання «Два платочки», «Шматок», «Омелько Каторжний», подані українською, вражають своєю емоційною наснаженістю, щирістю й довірливістю тону, тонким ліризмом, глибоким драматизмом відтворення людських доль, високим гуманізмом.

На думку сучасних дослідників І. Немченка, В. Загороднюка, Я. Голобородька, «Степ» став помітним літературно-мистецьким явищем своєї доби. Видання альманаху в умовах того часу «сприймалося мало не як акт громадянської мужності» $[10,18]$.

Як і варто було очікувати, активна просвітницька діяльність Д. Марковича в Херсоні викликала гостре незадоволення з боку представників адміністрації. Так, зокрема, генерал-губернатор Рооп написав листа до міністра юстиції, де звинуватив письменника-юриста в різних гріхах, допущених і в Єлисаветграді, і в Херсоні. Йшлося передусім про українофільство, зв'язки з політично неблагонадійними, з точки зору урядовців, людьми. Вказувалося, що, працюючи в Херсонському окружному суді, Д. Маркович мав «тісні стосунки 3 політично не благонадійними особами та особливо з тими, що перебувають в Херсоні Русовим, згрупувавши біля себе цілий гурток 
земських статистиків вельми сумнівного образу думок» [12]. Для цієї громади Дмитро Васильович був «своим товарищем и покровителем, к которому они нередко обращаются за советом и руководством» [12]. Відтак генерал-губернатор Рооп приходить до висновку: «Визнаючи всього вищевикладеного, що тривалі і наполегливі зносини г. Марковича 3 політично неблагонадьожними кружками Херсона, а також від часті Таврійської губернії представляється безсумнівним злом, яке більш терпимо бути не може, я вважаю своїм обов'язком про вищевикладене довести до відома Вашого Високості, уклінно просячи розпорядження, якщо служба г. Марковича може бути більш терпима в Міністерстві юстиції, то хоча про переведення його з меж ввіреного мені краю на Ваш розсуд» [12].

Чимало дослідників, зокрема сучасники альманаху, неоднозначно зустріли його появу у світі. Збірник «Степ» як «нове дітище українофільських муз» викликав інтерес І. Франка, який з приводу появи альманаху написав рецензію. Критик зазначив, що хоча «Степ» $\mathrm{i}$ претендує на «серйозне» видання, оскільки має обсяг 391 с., але його зміст «не зовсім відповідає цій претензії» [16, 114]. Фактично з перших рядків своєї праці Франко дає зрозуміти що упорядники поспішили та багато в чому недопрацювали. А закінчує огляд збірника взагалі словами: «... немає в ньому ( у «Степу» - В. Л.) жодного твору, який би додав якусь нову рису до характеристики свого автора, або ж для тих, хто вперше виступає, пророкував блискуче літературне майбутнє» $[16,116]$. Для Великого Каменяра залишається незрозумілим «чому її (збірку - В. Л.) названо белетристичним збірником, якщо, крім белетристичних творів, ми знаходимо в ній також праці наукові i - більше того - саме ці останні, хоч написані російською мовою, становлять основну вартість книжки?» $[16,114]$; «Далі, чому її названо херсонським збірником, якщо більшість представлених у ній авторів походить не з Херсона, а з різних частин України?» [16, 114].

На думку дослідників I. Немченка, [9] В. Загороднюка [3], адресовані I. Франком звинувачення щодо «Степу» не повністю слушні, адже зазначити, що наукові праці «становлять основну вартість книжки» буде не зовсім правильно. Власне, сам же Франко згодом дасть цьому підтвердження. Також І. Франко помилився щодо співавторів альманаху, майже кожен із яких так чи інакше був пов'язаний із Херсонщиною. Переважна більшість дописувачів у різний час жили і творили в Херсонській губернії: Д. Маркович, О. Браунер, П. Тулуб, К. Іващенко. Уродженцями тогочасної губерніальної Херсонщини (Єлисаветградського, Ананьївського чи іншого повіту) були I. Карпенко-Карий (Тобілевич), Дніпрова Чайка та ін. Згодом у наступній рецензії I. Франко визнає свої помилки. Його більше не хвилюють питання: «чому белетристичний» чи «названо херсонським»? Сам пише: «В р. 1886 спро- 
моглися херсонці на белетристичну збірку «Степ». Ба, навіть $є$ «відомі імена»... і велика література [17, 383].

Відгукнувся критичною публікацією про «Степ» і Б. Грінченко, який на момент виходу збірки жив і працював у Херсоні. Точніше, це Франко попросив його написати рецензію про збірник, яку згодом у 1887 р. було надруковано в журналі «Зоря» (№15-16). Варто зазначити, що рецензія Б. Грінченка була досить сувора й мала ось таку кінцівку: «От і все, що дає нам «Степ». Як бачите, можна було мати право більшого сподіватися, бо єсть у нас талановиті люде і чимало їх, - але ж... Але ж мабуть недурно у старих характеристиках Українця зазначено про «його» медлительность и наклонность к лени...» [6, 25].

Активно долучився до критики «Степу» і Володимир Ястребов, єлисаветградський історик. «Уже перша книга «Киевской старины» за 1887 відізвалася рецензією на єлисаветградський «Степ» [6, 22]. Автор говорить про те, що, на його думку, заслуговує на увагу й те, що ні. Так, приміром, п’єса І. Тобілевича рецензенту сподобалась - «бездоганний за своєї чистотою, образність і музичність мови та художній драматизм положень», «...натомість Пенчуківець не викликав жодних емоцій» [6, 23].

Висновок

Історія створення херсонського журналу «Степ», редакційна політика щодо формування авторського активу - це передусім повчальні уроки професіоналізму та патріотизму для нинішніх засновників та керівників засобів масової інформації.

\section{ЛIТЕРАТУРА}

1. Бойко А. Херсонський альманах «Степ» / А. Бойко // Південна Україна XVIII-XIX століття. - Вип. 6. - Запоріжжя, 2001. - С. 303-304.

2. Голобородько Я. Письменники і Херсон / Ярослав Голобородько. - Херсон : Персей, 2003. - 126 с.

3. Загороднюк В. Навчально-методичні рекомендації з курсу «Література Херсонщини» / Василь Загороднюк - Херсон : Видавництво ХДУ, 2004. - 20 с.

4. Каляка М. «Степові» - 110: Нарис про херсонський часопис. Історія альманаху «Степ» / Микола Каляка. - Херсон : Просвіта, 1996. - 8 с.

5. Конощенко А. Дніпрова Чайка : (Спогади) / Андрій Конощенко // Україна. - №5. 1927. - C. 121.

6. Лубчак В. Херсонський альманах «Степ»: дискусійні питання, гіпотези, перспективи / Вадим Лубчак. - Херсон : Айлант, 2006. - 56 с.

7. Маркович Д. Лист до Михайла Грушевського. 24 березня 1886 р. / Дмитро Маркович // Центральний державний історичний архів України, м. Київ. Ф. 1235. - Оп.1. - Спр. 630. - Арк. 1.

8. Михайлин I. Історія української журналістики XIX століття : [підручник] / Ігор Михайлин. - К. : ЦНЛ, 2003. - 720 с.

9. Немченко I. Дмитро Маркович і херсонський белетристичний збірник «Степ» (1886) / Іван Немченко. - Константи : Альманах соціальних досліджень. 1997. - № 2. - C. 15-20.

10. Немченко I. Незабутня квітка літературного Причорномор'я (До 115-річчя 3 часу виходу херсонського белетристичного збірника «Степ») / Іван 
Немченко. - Херсонський библиофил: 2000-2002 гг. : Альманах. - 2005. Вип. І. - С. 11-21.

11. Погребенник Ф. Український раритет. Періодичні, продовжувані видання і неперіодичні збірники XIX-XX ст. (1846-1986) / Ф. Погребенник,

В. Погребенник. - Дрогобич : Коло, 2011. - 300 с.

12. Poon X. Лист до міністра юстицій. / Христофор Рооп // Інститут рукопису Національної наукової бібліотеки ім. В. Вернадського НАН України. - Ф. 10. Спр. 34906. - Арк. 11.

13. Русова С. Мої спомини (1879-1915) / Софія Русова. - К. : ДВУ, 1928. - (За сто літ : Матеріали з громадського і літературного життя України XIX і початків XX століття; Кн. 3). - 163 с.

14. Рябінін-Скляревський О. Херсонський гурток Русова 1885-1889 / О. РябінінСкляревський. - Запоріжжя : Тандем-У, 2003. - 72 с.

15. Степ: Херсонський белетристичний збірник : [альманах]. - Херсон; СанктПетербург : видавництво Балешева, 1886. - 391 с.

16. Франко I. «Степ». Херсонський белетристичний збірник, Херсон, 1886 / Іван Франко. - К. : Наукова думка. Зібр. творів: У 50 т., Т. 27. - 1980. - С. 114-116.

17. Франко I. Нарис історії українсько-руської літератури до 1890 р. / Іван Франко. К. : Наукова думка. Зібр. творів: У 50 т., Т. 41. - 1984. - С. 194-470.

\section{REFERENCES}

1. Boiko A. (2001). Pivdenna Ukraina XVIII-XIX stolittia (South Ukraine of XVIII-XIX cent.). Zaporizhzhia, Ukraine: Kherson almanac “Step”, № 6, P. 303-304. (in Ukr.)

2. Holoborodko Ya. (2003). Pysmennyky i Kherson (Writers and Kherson). Kherson, Ukraine: Persey, P. 126. (in Ukr.)

3. Zahorodniuk $V$. (2004). Navchalno-metodychni rekomendatsii z kursu «Literatura Khersonshchyny» (Educational and methodical recommendations "Literature of Kherson region”). Kherson, Ukraine: Publishing house KhDU, P. 20. (in Ukr.)

4. Kaliaka M. (1996). «Stepovi» Narys pro khersonskyi chasopys. Istoriia almanakhu «Step» (Essay of Kherson magazine "Stepovi”. The history of "Step" almanac). Kherson, Ukraine: Prosvita, P. 8. (in Ukr.)

5. Konoshchenko A. (1927). Dniprova Chaika: (Spohady) (The Dnipro gull: (Memoirs). Ukraine: № 5, P. 121. (in Ukr.)

6. Lubchak V. (2006). Khersonskyi almanakh «Step»: dyskusiini pytannia, hipotezy, perspektyvy (Kherson almanac "Step": discussion questions, hypotheses, perspectives). Kherson, Ukraine: Ailant, P. 56. (in Ukr.)

7. Markovych D. (N. d.). Lyst do Mykhaila Hrushevskoho. 24 bereznia 1886 r. (The letter to Mykhailo Hrushevskyi. 24 of March 1886). Kyiv, Ukraine: Central State Historical Archives of Ukraine, F. 1235, Op. 1, № 630, Sheet 1. (in Ukr.)

8. Mykhailyn I. (2003). Istoriia ukrainskoi zhurnalistyky XIX stolittia (The history of Ukrainian journalism in XIX century). Kyiv, Ukraine: TsNL, P. 720. (in Ukr.)

9. Nemchenko I. (1997). Dmytro Markovych i khersonskyi beletrystychnyi zbirnyk «Step» (1886) (Dmytro Markovych and Kherson fiction collection "Step”). Konstants, Romania: Almanac of social researches, № 2, P. 15-20. (in Ukr.)

10. Nemchenko I. (2005). Nezabutnia kvitka literaturnoho Prychornomoria (Do 115-richchia z chasu vykhodu khersonskoho beletrystychnoho zbirnyka «Step») (The unforgettable flower of literal Black Sea region (By the 115th anniversary of the release of Kherson’s fiction collection “Step”). N. p.: Kherson’s bibliophile, № 1, P. 11-21. (in Ukr.)

11. Pohrebennyk V., Pohrebennyk F. (2011). Ukrainskyi rarytet. Periodychni, prodovzhuvani vydannia i neperiodychni zbirnyky XIX-XX st. (Ukrainian rarity. Periodic, continuing editions and nonperiodic collections of the XIX-XX centuries (1846-1986). Drohobych, Ukraine: Kolo, P. 300. (in Ukr.) 
12. Roop Kh. (N. d.). Lyst do ministra yustytsii (The letter to the Minister of Justice). Ukraine: V. Vernadskyi Institute of Manuscript of the National Scientific Library of NAS of Ukraine, F. 10, № 34906, Sheet 11. (in Ukr.)

13. Rusova S. (1928). Moi spomyny (1879-1915) Za sto lit : Materialy z hromadskoho i literaturnoho zhyttia Ukrainy XIX i pochatkiv XX stolittia (My remembrance (1879-1915) (For a hundred years: materials from the public and literary life of Ukraine in the 19th and early 20th centuries). Kyiv, Ukraine: DVU, B. 3, P. 163. (in Ukr.)

14. Riabinin-Skliarevskyi O. (2003). Khersonskyi hurtok Rusova 1885-1889 (Kherson Rusov's group 1885-1889). Zaporizhzhia, Ukraine: Tandem-U, P. 72. (in Ukr.)

15. Step: Khersonskyi beletrystychnyi zbirnyk: (almanakh) (Step: Kherson fictional collection: (almanac). (1886). Saint-Petersburg, Russia: Baleshev's publishing house, P. 391. (in Ukr.)

16. Franko I. (1980). «Step». Khersonskyi beletrystychnyi zbirnyk, Kherson, 1886 (“Step”. Kherson fictional collection, Kherson, 1886). Kyiv, Ukraine: Naukova dumka, T. 27, P. 114-116. (in Ukr.)

17. Franko I. (1984). Narys istorii ukrainsko-ruskoi literatury do 1890 r. (Essay of Ukrainian and Russian literature history till 1890). Kyiv, Ukraine: Naukova dumka, T. 41, P. 194-470. (in Ukr.)

\title{
KHERSON ANTHOLOGY “STEP” (STEPPE) IN THE HISTORY OF THE UKRAINIAN JOURNALISM
}

\author{
Lubchak Vadym, \\ Candidate of Sciences (Philology), Scientific researcher \\ T. Shevchenko Institute of Literature \\ National Academy of Science of Ukraine \\ 4 M. Grushevskyi str. \\ 01001, Kyiv, Ukraine \\ e-mail:vadim_lubchak@ukr.net
}

The article deals with the publishing history of Kherson anthology "The Steppe" (1886), with the role of O. Russov's group in this process. Special attention is paid to the peculiarities of the anthology preparation to publishing, authors and censorship restrictions.

The author of the research gives thorough analysis of literary-artistic quality of writings, submitted for the anthology, pays attention to works of both well-known then authors and young authors, unknown to the wide range of readers (D. Mordovets from Saint-Petersburg, Ivan Levytskyi (Nechui) from Kishinev, Mykhailo Hrushevskyi (Zavoloka) from Astrakhan, Pavlo Tuluba and Petro Zaloznyi from Kyiv, Kostia Ivashchenko (Shram) from Odessa).

This research proves the interference of the tsarist censorship, analyzes the damage to the anthology, done by constant fault-findings of censorship. Quoting the letters of compilers and authors of the anthology, the scientist proved the unprecedented importance of publishing the first Ukrainian anthology in the South of Ukraine for formation and strengthening national belles-lettres literature and journalism.

The author gives well-proved evidence that the publishing of the first Ukrainian anthology "The Steppe" in Kherson province created favorable situation for future literary and publishing projects. Special attention is paid to the reaction of that time Ukrainian and Russian critics on "The Steppe" and it is clarified why this publishing project proved to be commercially successful.

Key words: anthology "The Steppe", editor, compiler, literary process, Kherson literary society. 